\title{
Persepsi Siswa Terhadap Pelaksanaan Proses Belajar Mengajar Berbasis IT dalam Kondisi Pandemi Covid-19 di SMK Negeri 1 Sumatera Barat
}

\author{
Sasha Dilla Rakasiwi ${ }^{1 *}$ Donny Fernandez ${ }^{1}$ \\ ${ }^{1}$ Pendidikan Teknik Otomotif, Fakultas Teknik, Universitas Negeri Padang \\ Jln. Prof. Dr. Hamka Air Tawar Padang 25131 Indonesia \\ *1. sashadillara@gmail.com, ${ }^{2}$ fernandez_79@yahoo.co.uk \\ (Diajukan: 29 April 2021, direvisi: 27 Mei 2021, disetujui: 29 Mei 2021)
}

\begin{abstract}
Abstrak
Adanya perubahan pola pembelajaran tatap muka ke pembelajaran online berbasis IT selama pandemi covid-19, telah menyebabkan kebiasaan baru (new normal) terhadap proses pembelajaran. Penelitian ini mengungkapkan Persepsi Siswa Terhadap Pelaksanaan Proses Belajar Mengajar Berbasis IT Dalam Kondisi Pandemi Covid-19 Di SMK Negeri 1 Sumatera Barat. Metode yang digunakan yaitu penelitian Kuantitatif dengan pendekatan deskriptif, dengan bantuan program komputer (IBM SPSS Statistic 26). Penelitian terdiri dari tiga variabel yaitu teknologi. Individu dan lingkungan, dimana hasil penelitian mengungkapkan persepsi siswa terhadap kemampuan dan dukungan teknologi dalam mendukung pembelajaran online berada pada kategori baik, penilaian siswa terhadap kemapuannya dalam mengikuti pembelajaran berbasis IT berada pada kategori baik, dan selanjutnya persepsi siswa terhadap dukungan lingkungan dalam membantu mengikuti pembelajaran berbasis IT berada kategori cukup. Interprestasi dari ketiga variabel berada pada kategori baik. Hasil uji validitas setiap butir pernyataan dinyatakan valid karena $r_{\text {hitung }}$ setiap pernyataan $>\mathrm{r}_{\text {tabel }}$ (table $r$ product moment) dan uji reliabilitas dinyatakan reliabel karena $r_{\text {hitung }}>\mathrm{r}_{\text {tabel }}$.
\end{abstract}

Kata Kunci: Persepsi Siswa, Pembelajaran berbasis IT, Covid-19.

\begin{abstract}
The change in face to face learning patterns to IT based online learning during the Covid19 pandemic has led to new habits (new normal) in the learning process. This study revealed Student Perceptions of the Implementation of the IT-Based Teaching and Learning Process in the Conditions of the Covid-19 Pandemic at SMK Negeri 1 West Sumatra. The method used is quantitative research with a descriptive approach, with the help of a computer program (IBM SPSS Statistic 26). The study consisted of three variables, namely technology. Individuals and the environment, where the results of the research reveal students perceptions of the ability and technology support in supporting online learning are in a good category, students' assessments of their ability to take part in IT based learning are in a good category, and then students' perceptions of environmental support in helping to follow based learning IT is in the pretty category. The interpretation of the three variables is in the good category. The results of the validity test of each statement item were declared valid because $r$ counted each statement $>r$ table ( $r$ product moment table) and the reliability test was declared reliable because $r$ count $>r$ table.Keywords: content, formatting, article.
\end{abstract}

Keyword: Perception, IT based learning, Covid-19 


\section{PENDAHULUAN}

Pada disaat ini sistem pembelajaran di Indonesia yang berlangsung saat ini terjadi pergantian yang diakibatkan adanya pandemi (Covid-19), virus ini telah melanda bagian yang berdampak sangat utama di dunia pendidikan. Pendidikan saat ini sangat berperan penting untuk anak dalam kehidupan yang sesungguhnya. Hal tersebut berlangsung sebab besarnya pengaruh pada masa globalisasi. Pendidikan berperan sebagai langkah dini yang utama dalam individu anak untuk mengalami pertumbuhan jaman, lewat pendidikan anak dibekali dengan keahlian intelegensi, soft skill serta dan pendidikan kepribadian, religius serta melatih pengendalian emosional yang baik.

Pandemi virus corona telah masuk di Indonesia mengganti sistem pendidikan di sekolah dimana dampak pada akibat pandemi virus corona, membuat pembelajaran yang biasanya dilakukan disekolah akan tertular oleh siswa dan pembelajaran yang dilakukan dengan tatap muka pun berubah menjadi pembelajaran online berbasis IT, agar memutus rantai penyebaran virus corona. Akibatnya prosedur belajar yang biasanya dilakukan dengan tatap muka, ceramah serta interaksi fiksi ataupun secara langsung berganti sebagai online. Pendidikan online ini mulai serempak diaplikasikan pada tingkatan Sekolah Dasar (SD) hingga Sekolah Menengah maupun Kejuruan (SMA/SMK), mulai dari Taman Kanak-anak hingga Sekolah Tinggi atau Universitas semenjak pertengahan ataupun pada akhir bulan Maret 2020.

Tujuan pembelajaran dapat dikatakan berhasil bila reaksi belajar siswa mengalami perkembangan atau pertumbuhan serta peningkatan [1], terdapat pula yang dimaksud dari hasil belajar ialah hasil dari usaha belajar yang dilakukan siswa dalam pembelajaran formal kerap diikuti dengan evaluasi atau penilaian serta pengukuran demikian pula ketika metode belajar mengajar, dengan memahami hasil belajar yang dapat di ketahui kedudukan siswa yang pandai. Pada dasarnya pembelajaran ialah sesuatu metode untuk membentuk seorang menjadi individu yang lebih baik serta pembelajaran ialah sesuatu usaha sadar dan sengaja untuk membuat suasana belajar serta proses pembelajaran yang baik supaya partisipan didik secara efisien meningkatkan kemampuan dirinya untuk mempunyai kekuatan spiritual keagamaan, pengendalian diri, karakter, kecerdasan, akhlak mulia, dan keahlian yang diperlukan untuk dirinya, penduduk bangsa dan Negara [2]. Hal ini menekankan kalau pendidikan sebagai pondasi yang sangat berarti dalam proses terjadinya sumber energi manusia dalam suatu negeri buat meningkatkan kemampuan yang terdapat dalam diri tiap partisipan didik, diharapkan nantinya bermanfaat keperluan diri sendiri, masyarakat, maupun bangsa dan negara.

Dalam kondisi seperti ini bermacam-macam respon timbul pada saat kebijakan belajar lewat online dicoba atau dilaksanakan. Tidak cuma kedudukan orang tua peserta didik, akan tetapi pula dari golongan pendidik dan peserta didik. Pembelajaran secara online ini ialah prihal yang baru untuk mayoritas penduduk Indonesia, dari mula-mula nya pembelajaran dilakukan secara tatap muka maka hingga seketika dilakukan dengan jarak jauh ataupun secara online di segala institusi pendidikan. Persepsi sendiri telah banyak diteliti oleh banyak pihak salah satunya yang dilakukan oleh Priarti Megawati (2020) yang berjudul "Persepsi Peserta Didik Terhadap PJJ pada Masa Pandemi Covid19" menyatakan bahwa bersumber pada jawaban 155 responden nyaris seluruh 
responden yang terdiri dari jenjang SD hingga SMA sepakat bahwa mereka tidak senang dengan ketetapan perpanjangan masa belajar dari rumah. Terbentuknya persepsi dipengaruhi oleh faktor-faktor seperti pengalaman, latar belakang, pengetahuan, latar belakang fisik, sosial dan budaya, dan dapat disimpulkan persepsi itu merupakan hasil pikiran seseorang dari suasana tertentu. Tujuan dari penelitian ini yaitu Mengidentifikasi Permasalahan siswa Selama Proses Belajar Berbasis IT Dalam Kondisi Pandemi Covid-19 Di SMK Negeri Sumatera Barat. Dari latar belakang yang telah dijelaskan muncul pertanyaan penelitian yaitu Bagaimanakah Persepsi Siswa Terhadap Pelaksanaan Proses Belajar Mengajar Berbasis IT Dalam Kondisi Pandemi Covid-19 DI SMK Negeri 1 Sumatera Barat.

\section{Persepsi}

Persepsi yaitu pengalaman tentang gejala, kejadian, ataupun hubungan yang diperoleh dengan merumuskan serta menafsirkan pesan [3]. Bersumber pada penafsiran diatas persepsi muncul pada saat melihat suatu objek ataupun peristiwa melalui alat indera, setelah itu akan diperoleh serta merumuskan informasi tersebut. Persepsi ialah suatu proses gabungan dari persepsi yang akan diterima oleh organ serta hasil interpretasinya (reaksi oleh akal). Maksudnya hasil dari informasi yang ditangkap tersebut diperoleh lewat otak manusia. Persepsi sendiri digunakan untuk menyampaikan pengalaman terhadap suatu objek maupun sesuatu peristiwa yang dialami.

Persepsi mengarah lebih bersifat kognitif dari pada hanya metode penginderaan saja, sehingga terdapat sebagian aspek yang mempengaruhinya, semacam perhatian selektif, individu, yang memusatkan perhatiannya pada rangsangan-rangsangan tertentu saja. Persepsi ialah sesuatu proses yang didahului oleh proses penginderaan, yakni ialah proses diterimanya stimulus oleh pribadi lewat alat indera ataupun pula disebut proses sensoris [4]. Persepsi didefenisikan sebagai proses yang mengkombinasikan serta mengorganisasikan data-data indera (penginderaan) untuk dikembangkan sedemikian rupa sehingga bisa menyadari di sekitar, termasuk sadar akan diri sendiri [5].

\section{Model Pembelajaran Langsung (Direct Instruction)}

Model pembelajaran langsung ialah salah satu dari macam-macam model pembelajaran. Pembelajaran langsung ialah pembelajaran yang lebih menetapkan pada pengusaan konsep ataupun pendekatan disaat pengajaran yang bermulai dengan menyajikan peraturan, prinsip umum serta disertai dengan pelaksanaan peraturan ataupun contohcontoh yang khusus.

Ciri-ciri pembelajaran langsung [6], yaitu:

a. Terdapatnya target pembelajaran serta proses evaluasi belajar.

b. Susunan kata ataupun pola totalitas atau alur aktivitas pembelajaran.

c. Pola pengendalian dan daerah belajar yang menunjang berlangsung serta tercapainya pembelajaran.

\section{Pembelajaran Online}

Pembelajaran online secara luas ialah sesuatu pembelajaran yang dilakukan dengan media berbasis elektronik dan suatu jaringan yang dibuat untuk menunjang mengaksesnya. Belajar online ataupun dalam jaringan ini umumnya pula dikenal dengan istilah e-learning, virtual learning ataupun web based learning. Pembelajaran 
online ini sumber atau materinya diakses dari website, interconnected network (internet), CD-ROM serta DVD. Pembelajaran online ini tidak hanya mengakses data atau informasi namun pula menunjang para peserta didik dengan hasil-hasil yang berguna untuk menggapai tujuan. Tidak hanya menyampaikan pengajaran, e-learning ataupun lainnya dapat menunjang kinerja peserta didik dalam belajar serta memberi tahu kemajuan belajar peserta didik [7].

\section{Teknologi Informasi (IT)}

Internet merupakan jaringan yang mencakup beribu-ribu terlebih lagi berjuta-jutaan $p c$, terhitung di dalam jaringan lokal, bisa menghubungkan lewat gelombang (satelit, telefon, kabel) serta capaiannya meliputi segala tempat [8]. Penggunaan teknologi internet untuk pembelajaran di Indonesia secara formal diawali semenjak terwujudnya telematika tahun 1961. Pada ditahun yang sama dibangun Asian Internet Interconnetions Initiatives Jaringan yang dikoordinasikan oleh ITB ini yang bermaksud untuk pengenalan serta pengembangan teknologi internet untuk pendidikan dan riset, peningkatan backbone internet pembelajaran serta studi di kawasan Asia Pasifik bersamaan perguruan tinggi di kawasan ASEAN dan Jepang, serta pengembangan informasi internet yang meliputi bidang ilmu pengetahuan, teknologi, budaya, sosial, dan ekonomi.

Komunikasi lewat internet bisa dilakukan secara interpersonal (misalnya email serta chatting) ataupun secara masal, yang sering dikenal one to many communication (misalnya Mailing List). Internet juga dapat muncul secara real time audio visual seperti pada metode konvensional dengan adanya aplikasi teleconference.

\section{Pandemi Covid-19}

Di saat ini dunia tengah dilanda peristiwa yang sangat luar biasa yakni coronavirus. Coronavirus ialah keluarga besar virus yang menimbulkan penyakit mulai dari indikasi ringan hingga yang berat. Ada dua jenis coronavirus yang dikenal menimbulkan indikasi atau gejala berat seperti Middle East Respiratory Syndrome (MERS) dan Severe Acute Respiratory Syndrome (SARS). Di Indonesia, pemerintah mengkonfirmasi permasalahan covid-19 diawal tanggal 2 Maret 2020 walaupun timbul sebagian spekulasi bahwa covid-19 sudah masuk ke Indonesia beberapa waktu sebelumnya [9]. Pandemi virus corona telah masuk di Indonesia merubah sistem pembelajaran di sekolah dimana dampak pada akibat pandemi virus corona, membuat pembelajaran yang biasanya dilakukan disekolah akan tertular oleh siswa dan pembelajaran yang dilakukan dengan tatap muka pun berubah menjadi pembelajaran online berbasis IT, agar memutus rantai penyebaran virus corona.

\section{METODE}

Penelitian ini termasuk pada penelitian deskriptif maksudnya sesuatu prosedur dalam mempelajari atau meneliti status sekelompok manusia, sesuatu objek, sesuatu kondisi, sesuatu sistem pemikiran, ataupun sesuatu kelas kejadian pada masa saat ini [10]. Metode penelitian merupakan cara ilmiah buat memperoleh informasi dengan tujuan serta manfaat tertentu [11]. Metode penelitian yang digunakan dalam penelitian ini yaitu penelitian kuantitatif. Sampel dalam penelitian adalah 61 orang siswa X TKRO.

\section{Teknik Pengumpulan Data}


1. Angket (Questionnaire)

Angket ialah pengumpulan data atau informasi yang dilakukan dengan cara memberi kesepakatan persoalan atau pertanyaan tertulis kepada responden agar untuk dijawabnya. Angket ialah teknik pengumpulan data yang efektif apabila peneliti ketahui dengan pasti variabel yang hendak diukur serta diketahui apa yang dapat diharapkan dari responden [12].

2. Dokumentasi

Dokumentasi merupakan untuk mendapatkan data langsung dari tempat penelitian, meliputi buku-buku yang relevan, peraturan-peraturan, laporan aktivitas, foto-foto, film, dokumentar, data atau informasi yang relevan penelitian [7].

\section{Uji Coba Instrumen Penelitian}

Uji coba instrumen dilakukan agar mengetahui serta memilih butir-butir yang sahih. Dengan uji coba instrumen ini akan diketahui apakah instrumen yang dipakai layak untuk menjadi alat ukur dalam mengumpulkan data [10].

a. Uji validitas

uji validitas merupakan sesuatu dimensi atau ukuran yang menampilkan tingkattingkat kevalidan ataupun ketetapan suatu instrumen [10]. Uji validitas digunakan untuk mencari kevalidan suatu item pernyataan dalam angket. Berdasarkan hasil uji validitas, seluruh pernyataan dalam angket dikatakan valid karena $r_{\text {hitung }}>$

$r_{\text {tabel }}$ (product moment yaitu 0,361). Uji validitas dalam menentukan kevalidan instrumen menggunakan bantuan program IBM SPSS Statistic 26.

b. Uji reliabilitas

Tabel 1. Uji Releabilitas

\begin{tabular}{|c|c|}
\hline \multicolumn{2}{|c|}{ Reliability Statistics } \\
\hline Cronbach's Alpha & N of items \\
\hline 0.928 & 32 \\
\hline
\end{tabular}

Suatu instrumen bisa dinyatakan reliabel bila $r_{\text {hitung }}>r_{\text {tabel }}$ dengan taraf signifikan 5\% dan sebaliknya instrumen tidak dapat dikatakan reliabel jika $r_{\text {hitung }}$ $<r_{\text {tabel }}$ dengan taraf signifikan 5\%. Uji reliabilitas instrumen menunjukkan $r_{\text {hitung }}$ $>r_{\text {tabel }}$ dengan taraf signifikan sebesar 5\% dimana $r_{\text {hitung }}(0,928)>$ $r_{\text {tabel }}(0,361)$.

\section{Langkah-Langkah Penyusunan Instrunen}

Langkah-langkah penyusunan instrumen menentukan indikator dari variabel yang akan diteliti, membuat kisi-kisi angket berdasarkan indikator. Menyusun butir-butir angket berdasarkan indikator yang telah ditetapkan. Mengkonsultasi butir-butir angket dengan pembimbing, melakukan uji coba angket, menganalisis hasil uji coba untuk mengetahui rata- rata (mean), uji validitas dan uji reliabilitas angket. Untuk menetukan kualitas dari persepsi siswa terhadap pelaksanaan proses belajar mengajar berbasis IT dalam kondisi pandemi dengan menggunakan batas nyata skala linkert yang dikemukakan [13], seperti pada Tabel 2. 
Tabel 1. Interprestasi Tingkat Capaian Skor

\begin{tabular}{cc}
\hline Skor & Kategori \\
\hline $4,6-5,0$ & Sangat Baik \\
$3,6-4,5$ & Baik \\
$2,6-3,5$ & Cukup Baik \\
$1,6-2,5$ & Kurang Baik \\
$0,6-1,5$ & Tidak Baik \\
\hline
\end{tabular}

\section{HASIL DAN PEMBAHASAN}

Berdasarkan hasil penelitian yang dilakukan di SMK Negeri 1 Sumatera Barat. Objek dari penelitian ini adalah siswa kelas X TKRO 1 dan X TKRO 2. Data dari penelitian ini diperoleh dengan cara menyebar angket. Penelitian ini terdiri dari dua variabel yaitu persepsi siswa terhadap proses belajar mengajar berbasis IT (X) dan pelaksanaan proses belajar mengajar berbasis IT di masa pandemi (Y). Maka diperoleh data mengenai persepsi siswa dengan variable teknologi $\left(\mathrm{X}_{1}\right)$, individu $\left(\mathrm{X}_{2}\right)$ dan lingkungan $\left(\mathrm{X}_{3}\right)$.

Tabel 2. Persepsi Siswa Dilihat Dari Variable Teknologi $\left(\mathrm{X}_{1}\right)$

\begin{tabular}{|c|c|c|c|c|c|c|c|c|c|c|c|c|c|c|}
\hline \multirow{2}{*}{ No } & \multirow{2}{*}{ Kode Soal } & \multicolumn{5}{|c|}{$\mathrm{T}$} & \multicolumn{5}{|c|}{ Tx SL } & \multirow{2}{*}{$\mathrm{n}$} & \multirow{2}{*}{ TCR } & \multirow{2}{*}{ Rata-Rata } \\
\hline & & SS & ST & $\mathrm{N}$ & TS & STS & 5 & 4 & 3 & 2 & 1 & & & \\
\hline 1 & $\mathrm{X} 1$ & 10 & 13 & 6 & 2 & 0 & 50 & 52 & 18 & 4 & 0 & 31 & 124 & 4.0 \\
\hline 2 & $\mathrm{X} 2$ & 9 & 12 & 5 & 5 & 0 & 45 & 48 & 15 & 10 & 0 & 31 & 118 & 3.8 \\
\hline 3 & X3 & 8 & 11 & 7 & 5 & 0 & 40 & 44 & 21 & 10 & 0 & 31 & 115 & 3.7 \\
\hline 4 & $\mathrm{X} 4$ & 11 & 13 & 4 & 3 & 0 & 55 & 52 & 12 & 6 & 0 & 31 & 125 & 4.0 \\
\hline 5 & X5 & 11 & 16 & 3 & 1 & 0 & 65 & 64 & 3 & 2 & 0 & 31 & 134 & 4.3 \\
\hline 6 & X6 & 13 & 16 & 1 & 1 & 0 & 65 & 64 & 3 & 2 & 0 & 31 & 134 & 4.3 \\
\hline 7 & $X 7$ & 9 & 21 & 1 & 0 & 0 & 45 & 84 & 3 & 0 & 0 & 31 & 132 & 4.3 \\
\hline 8 & $\mathrm{X} 8$ & 10 & 18 & 1 & 2 & 0 & 50 & 72 & 3 & 4 & 0 & 31 & 129 & 4.2 \\
\hline 9 & X9 & 14 & 15 & 2 & 0 & 0 & 70 & 60 & 6 & 0 & 0 & 31 & 136 & 4.4 \\
\hline 10 & $\mathrm{X} 10$ & 7 & 15 & 9 & 0 & 0 & 35 & 60 & 27 & 0 & 0 & 31 & 122 & 3.9 \\
\hline 11 & X11 & 8 & 13 & 6 & 4 & 0 & 40 & 52 & 18 & 8 & 0 & 31 & 118 & 3.8 \\
\hline 12 & $\mathrm{X} 12$ & 10 & 15 & 5 & 1 & 0 & 50 & 60 & 15 & 2 & 0 & 31 & 127 & 4.1 \\
\hline 13 & $\mathrm{X} 13$ & 7 & 12 & 9 & 2 & 1 & 35 & 48 & 27 & 4 & 1 & 31 & 115 & 3.7 \\
\hline 14 & X14 & 10 & 15 & 4 & 2 & 0 & 50 & 60 & 12 & 4 & 0 & 31 & 126 & 4.1 \\
\hline & & & & & & Rata-R & & & & & & & & 4.0 \\
\hline
\end{tabular}

Pada Tabel 2 diperlihatkan keseluruhan persepsi siswa terhadap proses belajar mengajar berbasis IT terhadap variabel teknologi mendapatkan skor rata-rata 4,0. Skor ini berada pada kategori baik. Artinya persepsi siswa terhadap proses belajar mengajar berbasis IT dalam kondisi covid-19 di SMK Negeri 1 Sumatera Barat bisa dikatakan sudah baik dilihat pada tabel interprestasi tingkat capaian skor.

Sedangkan pada Tabel 3 ditujukkan keseluruhan persepsi siswa terhadap proses belajar mengajar berbasis IT terhadap variabel individu mendapatkan skor rata-rata 4,1. Skor ini berada pada kategori baik. Artinya persepsi siswa terhadap proses belajar mengajar berbasis IT dalam kondisi covid-19 di SMK Negeri 1 Sumatera Barat bisa dikatakan sudah baik baik dilihat pada tabel interprestasi tingkat capaian skor.

Penelitian ini telah menemukan gambaran tentang persepsi merupakan pengalaman tentang objek, peristiwa, ataupun hubungan-hubungan yang diperoleh dengan merumuskan serta menafsirkan pesan [4]. Persepsi siswa terhadap pelaksanaan proses belajar mengajar berbasis IT dalam kondisi pandemi covid-19 di SMK Negeri 1 
Sumatera Barat. Dalam penelitian ini terlebih dahulu dilakukan pengujian angket terdapat 32 butir pertanyaan, seluruh pernyataan dinyatakan valid dan reliabel. Data penelitian untuk variabel teknologi yang diantaranya menyangkut tentang ketersediaan dan pemahaman diperoleh nilai rata-rata 4,0, variabel individu diantaranya menyangkut kepribadian siswa diperoleh nilai rata-rata 4,1 dan variabel lingkungan menyangkut pada tempat siswa diperoleh nilai rata-rata 3,3 dan rekapitulasi hasil diperoleh rata-rata 3,8 dengan kategori baik

Tabel 3. Persepsi Siswa Dilihat Dari Variable Individu $\left(\mathrm{X}_{2}\right)$

\begin{tabular}{|c|c|c|c|c|c|c|c|c|c|c|c|c|c|c|}
\hline \multirow{2}{*}{ No } & \multirow{2}{*}{$\begin{array}{l}\text { Kode } \\
\text { Soal }\end{array}$} & \multicolumn{5}{|c|}{$\mathrm{T}$} & \multicolumn{5}{|c|}{$\mathrm{T} \times \mathrm{SL}$} & \multirow{2}{*}{$\mathrm{n}$} & \multirow{2}{*}{ TCR } & \multirow{2}{*}{ Rata-Rata } \\
\hline & & SS & ST & $\mathrm{N}$ & TS & STS & 5 & 4 & 3 & 2 & 1 & & & \\
\hline 1 & $\mathrm{X} 15$ & 8 & 19 & 3 & 1 & 0 & 40 & 76 & 9 & 2 & 0 & 31 & 127 & 4.1 \\
\hline 2 & $\mathrm{X} 16$ & 8 & 18 & 2 & 3 & 0 & 40 & 72 & 6 & 6 & 0 & 31 & 124 & 4.0 \\
\hline 3 & $\mathrm{X} 17$ & 8 & 19 & 2 & 2 & 0 & 40 & 76 & 6 & 4 & 0 & 31 & 126 & 4.1 \\
\hline 4 & $\mathrm{X} 18$ & 6 & 23 & 1 & 1 & 0 & 30 & 92 & 3 & 2 & 0 & 31 & 127 & 4.1 \\
\hline 5 & X19 & 10 & 14 & 4 & 3 & 0 & 55 & 60 & 12 & 2 & 0 & 31 & 129 & 4.2 \\
\hline 6 & $\mathrm{X} 20$ & 11 & 15 & 4 & 1 & 0 & 55 & 60 & 12 & 2 & 0 & 31 & 129 & 4.2 \\
\hline 7 & $\mathrm{X} 21$ & 9 & 15 & 5 & 2 & 0 & 45 & 60 & 15 & 4 & 0 & 31 & 124 & 4.0 \\
\hline 8 & $\mathrm{X} 22$ & 12 & 13 & 4 & 2 & 0 & 60 & 52 & 12 & 4 & 0 & 31 & 128 & 4.1 \\
\hline 9 & $\mathrm{X} 23$ & 14 & 10 & 5 & 2 & 0 & 70 & 40 & 15 & 4 & 0 & 31 & 129 & 4.2 \\
\hline 10 & $\mathrm{X} 24$ & 8 & 18 & 3 & 2 & 0 & 40 & 72 & 9 & 4 & 0 & 31 & 125 & 4.0 \\
\hline 11 & $\mathrm{X} 25$ & 11 & 17 & 1 & 1 & 1 & 55 & 68 & 3 & 2 & 1 & 31 & 129 & 4.2 \\
\hline 12 & X26 & 7 & 22 & 2 & 0 & 0 & 35 & 88 & 6 & 0 & 0 & 31 & 129 & 4.3 \\
\hline \multicolumn{14}{|c|}{ Rata-Rata } & 4.1 \\
\hline
\end{tabular}

Tabel 4. Persepsi Siswa Dilihat Dari Variable Lingkungan $\left(\mathrm{X}_{3}\right)$

\begin{tabular}{|c|c|c|c|c|c|c|c|c|c|c|c|c|c|c|}
\hline \multirow{2}{*}{ No } & \multirow{2}{*}{$\begin{array}{c}\text { Kode } \\
\text { Soal }\end{array}$} & \multicolumn{5}{|c|}{$\mathrm{T}$} & \multicolumn{5}{|c|}{ Tx SL } & \multirow{2}{*}{$\mathrm{n}$} & \multirow{2}{*}{ TCR } & \multirow{2}{*}{ Rata-Rata } \\
\hline & & SS & ST & $\mathrm{N}$ & TS & STS & 5 & 4 & 3 & 2 & 1 & & & \\
\hline 1 & $\mathrm{X} 27$ & 7 & 4 & 8 & 9 & 3 & 35 & 16 & 24 & 18 & 3 & 31 & 96 & 3.1 \\
\hline 2 & $\mathrm{X} 28$ & 5 & 7 & 9 & 10 & 0 & 25 & 28 & 27 & 20 & 0 & 31 & 100 & 3.2 \\
\hline 3 & X29 & 7 & 11 & 4 & 8 & 1 & 35 & 44 & 12 & 16 & 1 & 31 & 108 & 3.5 \\
\hline 4 & X30 & 8 & 13 & 7 & 3 & 0 & 40 & 52 & 21 & 6 & 0 & 31 & 119 & 3.8 \\
\hline 5 & X31 & 4 & 4 & 9 & 7 & 7 & 5 & 4 & 78 & 4 & 2 & 31 & 91 & 2.9 \\
\hline 6 & X32 & 1 & 2 & 26 & 2 & 2 & 5 & 4 & 78 & 4 & 2 & 31 & 91 & 2.9 \\
\hline \multicolumn{14}{|c|}{ Rata-Rata } & 3.3 \\
\hline
\end{tabular}

Tabel 4, memperlihatkan keseluruhan persepsi siswa terhadap proses belajar mengajar berbasis IT terhadap variabel individu mendapatkan skor rata-rata 3,3. Skor ini berada pada kategori cukup baik. Artinya persepsi siswa terhadap proses belajar mengajar berbasis IT dalam kondisi covid-19 di SMK Negeri 1 Sumatera Barat bisa dikatakan cukup baik baik dilihat pada tabel interprestasi tingkat capaian skor.

Secara umum, dari ketiga variable yang ada maka rekapitulasi hasil persepsi siswa terhadap proses belajar mengajar berbasis IT dalam kondisi pandemic Covid-19 dapat disimpulkan seperti pada Tabel 5.

Tabel 5. Rekapitulasi Hasil

\begin{tabular}{cccc}
\hline No & Indikator & Rata-rata & Kriteria \\
\hline 1 & Teknologi & 4,0 & Baik \\
2 & Individu & 4,1 & Baik \\
3 & Lingkungan & 3,3 & Cukup Baik \\
\hline & Rata-rata & 3,8 & Baik \\
\hline
\end{tabular}


Berdasarkan Tabel 5, terdapat rata-rata variable individu yang paling tinggi dengan skor 4,1. Dengan demikian dapat dikatakan bahwa persepsi siswa terhadap pelaksanaan proses belajar mengajar berbasis IT dalam kondisi pandemi covid-19 di SMK Negeri 1 Sumatera Barat pada kategori baik dengan skor rata-rata keseluruhan 3,8.

Penelitian ini telah menemukan gambaran tentang persepsi merupakan pengalaman tentang objek, peristiwa, ataupun hubungan-hubungan yang diperoleh dengan merumuskan serta menafsirkan pesan [4]. Persepsi siswa terhadap pelaksanaan proses belajar mengajar berbasis IT dalam kondisi pandemi covid-19 di SMK Negeri 1 Sumatera Barat. Dalam penelitian ini terlebih dahulu dilakukan pengujian angket terdapat 32 butir pertanyaan, seluruh pernyataan dinyatakan valid dan reliabel. Data penelitian untuk variabel teknologi yang diantaranya menyangkut tentang ketersediaan dan pemahaman diperoleh nilai rata-rata 4,0, variabel individu diantaranya menyangkut kepribadian siswa diperoleh nilai rata-rata 4,1 dan variabel lingkungan menyangkut pada tempat siswa diperoleh nilai rata-rata 3,3 dan rekapitulasi hasil diperoleh rata-rata 3,8 dengan kategori baik.

\section{KESIMPULAN DAN SARAN}

Berdasarkan hasil penelitian dan pembahasan yang telah diuraikan, maka diperoleh kesimpulan bahwa Persepsi siswa terhadap pelaksanaan proses belajar mengajar berbasis IT dalam kondisi pandemi covid-19 di SMK Negeri 1 Sumatera Barat, pada hasil variabel teknologi diperoleh skor 4,0 dengan kategori baik, variabel lingkungan diperoleh skor 4,1 dengan kaegori baik dan variabel lingkungan diperoleh skor 3,3 dengan kategori cukup. Rekapitulasi yang diperoleh dengan rata-rata 3,8 dengan kategori baik, karena siswa masih melaksanakan proses belajar mengajar berbasis IT dalam kondisi pandemi covid-19 saat ini dengan baik dan berjalan sesuai dengan semestinya. Uji validitas yang dilakukan untuk seluruh pernyataan dinyatakan valid dan uji reliabilitas juga dinyatakan reliabel karena $r_{\text {hitung }}(0,928)>r_{\text {tabel }}(0,361)$ dengan taraf signifikan sebesar 5\%. Hal ini dapat mengetahui tujuan dari penelitian ini yaitu Mengidentifikasi Permasalahan siswa Selama Proses Belajar Berbasis IT Dalam Kondisi Pandemi Covid-19 Di SMK Negeri Sumatera Barat.

Berdasarkan penelitian, pembahasan dan kesimpulan yang telah disampaikan, maka dapat dikemukakan saran-saran sebagai berikut : Pertama, pada variabel lingkungan memiliki rata-rata terendah dari ketiga variabel tetapi masih dikategorikan cukup baik, maka penulis menyarankan kepada siswa untuk lebih meningkatkan kepercayaan diri sendiri dan tidak terpengaruh terhadap lingkungan luar atau sekitar pada saat pelaksanaan proses belajar mengajar berbasis IT dalam kondisi pandemi saat ini. Kedua, guru sebagai staf pengajar di SMK Negeri 1 Sumatera Barat agar mengajak siswanya untuk lebih menggemari kegiatan membaca dan guru juga perlu memotivasi siswa agar lebih giat dalam melakukan proses pembelajaran terutama pada saat ini. Ketiga, bagi penyempurnaan penelitian ini, bagi peneliti lain yang ingin meneliti ini agar dapat memperluas kajian-kajian dengan aspek-aspek lain. 


\section{REFERENSI}

[1] A. S. Rahman, B. Mulyani, and S. Yamtimah, "Penerapan Pembelajaran Model Problem Posing Untuk Meningkatkan Kreativitas Dan Prestasi Belajar Siswa Pada Materi Laju Reaksi Kelas XI IPA 5 SMA Negeri 1 Boyolali Tahun Pelajaran 2012/2013," J. Pendidik. Kim. Univ. Sebel. Maret, vol. 2, no. 2, pp. 1-6, 2013.

[2] Sisdiknas, Sistem pendidikan nasional. Indonesia, 2003.

[3] J. Rakhmad, Psikologi komunikasi. Bandung: PT. Remaja Rosdakarya, 2010.

[4] B. Walgito, Pengantar psikologi umum. Yogyakarta: CV andi Offset, 2010.

[5] A. rahman Shaleh, Psikologi Suatu Pengantar Dalam Perspektif Islam. Jakarta: Kencana prenada media group, 2015.

[6] D. Widaningsih, Perencanaan pembelajaran. Bandung: Rizqi Press, 2010.

[7] S. . Smaldino, D. . Lowther, and J. . Russel, Teknologi pembelajaran dan media untuk belajar. Jakarta: Kencana, 2011.

[8] A. H. Suyanto, “Mengenal learning,"http://asephs.web.ugm.ac.id/artikel/elearning/ pengenalan\%20 elearning.pdf., 2005 .

[9] Kemenkes, Pedoman pencegahan dan pengendalian corona virus desease (Covid19): Kementrian kesehatan RI direktorat jenderal pencegahan dan pengendalian penyakit $(P 2 P)$. Indonesia, 2020.

[10] Nazir, Metode Penelitian. Bogor: Ghalia Indonesia, 2014.

[11] S. Suryabrata, Metode penelitian. Bandung: Alfabeta, 2012.

[12] Sugiyono, Metode penelitian kuantitatif. Jakarta: PT. Raja grafindo persada, 2018.

[13]L. DJ, Evaluasi pendidikan. Padang: UNP Press, 2011. 
Halaman ini sengaja dikosongkan 